变を SE 法の T1 強調, T2 强調, プロトン強調などで描出するのは 難しい.MRAの画質向上に用いら机ているMTC（通常のパルスシ ーケンスの前に off-resonance ハルスを照射することによって, 高 分子に結合するプロトンと自由水のプロトンの間に新たなコント ラストを生み出す方法)を，眎関節に用いることにより関節軟骨々 関節淮がコントラストよく描出されることで, 滕関節軟骨病変の診 断に有用な撮像バラメータの発表であった。

4. MIP 処理の軟部疾患への応用 MRA 再構成に用いられて いるMIP 法（maximum intensity projection）を乳房に用いるこ 上により病変上血管系が同時に強調描出されることで診断の手助 けになる発表であった。

5.脳の ${ }^{1} \mathrm{H}-$ MRS のルーチン化へ向けての適応範囲の検討

${ }^{2} \mathrm{H}-M R S$ は，今だ確立されたものはなく発展途上にあるので，主 してや臨床的評洒は一部で有用々いう報告もあるが定まっていな いのが現状である。その原因のびとつの要素にシミング（shim ming：磁場均一性を高內る操作）に時間を要したというのがあっ た，発表では，シミングの自動化により時間的制約もなくなりル ル ーチン検相で良好なスベクトルが得られるようになった。

これから症例を重极ることで臨床的評価が定まることを期待す る.

6.おわりに 従来の撮像テクニックを熟成した発表が汪とん どであったが，発表のための撮像テクニックではなく，臨床の分野 に還元されるような撮像テクニックであるように今後も期待した 1).

\section{乳房検査技術座長 丹野律子（対がん釧路センター）}

5. マンモグラフィ技術の最適化（第 1 報）一道内におけるマンモ グラフィの実態調査一

北海道対がん協会

二石岡 亮・鉿木康雄・郓野雅浩・小生田学・根本英光 北海道のマンモグラフィ（以下 MMG）の現状を把握しその問題 点上今後の課題について分析検討を行った。方法は，アンケート方 式により MNG 実施施設（93件，回收率 $门 .3 \%$ ）を対象にX線装 置，撮影技術，現像処理，品質管理について調查した。集計結果上 り M M MG 専用撮影装置は，前回調査より $15 \%$ 增加の $67.2 \%$ であっ た。しかし残り $32.8 \%$ のうち $19.4 \%$ は，いまだ一般装置の使用であ り，早急な改善が必要であった。その他高画質を得る為に必要なグ リッドの使用では，38.8\%と低率を示し，また品質管理は，殆ど夷 施されていないのが現状であった。

本調查で，MNG に対する設请面，技術面での立ち遅れは甚だし く，装置の規格化，専用管球の使用などハード面での調整々，撮影 技術の標準化の浸透が急務であると思われた。このためには，全国 的に統一された規格（ガイド）の制定が重要であると考える。

6. マンモグラフィ技術の最適化 (第 2 報) - ACR 公認ファントム を用いた MMG 画質の検討一

北海道対がん協会

少车田学・鉿木康雄・鵜野雅浩・根本英光・石岡 亮

〔目的〕第 1 報で行ったアンケート結果をもとに，ACR 公認】 アントムを用い, 専用装置を所有している主要施設のマンモグラフ

亿（以下，MMG）の画質調査を実施した。

その調查内容より，MMGにおいて，画質に影響を与える要因を 分析し，これらを検討した。

〔方法〕 ACR 公諗ファントムである，RMI 社製156型ファント
ムを用い，フィルムのガンマによる違い，ブッキーの使用の有無， 現像処理速度について，MMGの画質への影響を検討した。

【結果：MMGの画質を改善するには，以下のことを確認した。

1. 高ガンマのフィルムを使用する。

2.プッキーを使用することが望ましい.

3. 迅速現像処理は，現状では適さない。

7. RMI 社製マンモグラフィ $\mathrm{QC}$ キット182型について

市立隶館病院 ○橋本泰弘

(目的)マンモグラフィ（以下 MMG）は，ほかのX線撮影画像 に此べ高い品質管理が要求される，そこで今回我々は MMG 装置 導入時に RMI 社製 MNGQC キット182型を同時に購入し，これを 使用して据え付け時の検査を行い, 総合的画像管理についての有用 性を検討した。

〔方法〕測定は，管電圧，撮影時間，焦点サイズ，半価層，画質 評価, 増感紙一フィルム密着試験, 被曝線量について行った。

〔結果；管電死は土 $1 \mathrm{kVp}$ 以内で事前にオシロスコープで測定 した結果とほ隹一致した。画質評価ではグリット十で9点で特に一 般撮影現像系との共用が問題々思われた。その他の測定についても 容易に再現性良く測定可能であることが確認され MMG 画像の品 質管理に有用であった。

8. 乳腺超音波所見の計量化の検討一腫瘜性病变を対象として一 北厚生連 帯広厚生病院

○岩田恵俊・辻野和徳・上田章裕・山田和夫 ・ 木村和善 当院では，乳腺超音波検査仕放射線技師が行い，依頼医師へ情報 を提供しているが，画像に良性悪性の所見が十分反映し表現されて いるかどうか検討されていないのが現状である。放射線技師の立場 から、より客観的な情報を提供するためには，術者の違いにより生 ずる主観的要因を排除する必要がある。そこで，病理学的診断を基 によ゙の程度相関しているかを多変量解析に基づく分析を行い統計 学的計量化を試み，放射線技師の持つべき診断基準の一つとなり得 るかを検証する。

超音波画像を基に，日本超音波医学会医用超音波䛦断基準に関亦 る委員会が提唱しているて項目について放射線技師う名によって 読影し多変量解析を行い病理学的診断を基に, 良性悪性の判定を行 った.

カイ自乗検定の結果，形状・辺縁・内部エコーについて $\mathrm{P} \leqq 0.01$ と有意差を認め，判別的中率は $72.1 \%$ であった。

\section{座長集約}

演題 5 は, 道内におけるマンモグラフィの実態調査を実施し，そ の内容について分析したものである. 専用装置を使用している施設 は，87年の調査に比べ，15\%程増加しているが，品質管理に関して は実施している施設はほとんどなく，高品位の画像を得られている 施設は少ないと思われる状況にあるとの報告であった。

演題 6 は, 演題 5 のアンケート結果を基に ACR 公認ファントム を用いて画質調查を実施し，マンモグラフィの画質に影響を与える 因子について述べたものである.フィルムはガンマの高いもの程評 価が高く，また，ブッキーの有無についてはブッキー使用時の方が 良い評洒となった。次に現像処理に関しては，近年迅速処理化が進 んでいるが，45秒処理では90秒処理に比べてがンマが低くなる傾向 にあり，粒状性，フィルムの污れに問題があるとの報告であった。

演題 7 は QCキットを用いて専用装置の品質管理を行い, その有 用性を検討したものである．各測定項目の中で，ファントムを用い 